\title{
Endotoxin Induces Glutathione Reductase Activity in Lungs of Mice
}

\author{
DONNA C. HAMBURG, HIDEFUMI TONOKI, STEPHEN E. WELTY, ROBERT S. GESKE, \\ CHARLES A. MONTGOMERY, AND THOMAS N. HANSEN \\ Section of Neonatology, Department of Pediatrics and Department of Cell Biology, Baylor College of Medicine, \\ Houston, Texas 77030
}

\begin{abstract}
Glutathione reductase catalyzes the NADPH-dependent conversion of glutathione disulfide to glutathione and helps protect the lung from injury by reactive oxygen. In animals allowed to breathe nearly $100 \%$ oxygen, the activities of other antioxidants in the lung can be induced by treatment with endotoxin, and this induction is associated with increased tolerance to hyperoxia. The purpose of this study was to see whether glutathione reductase activity in the lungs of mice increased with endotoxin treatment alone. We studied 60 FVB mice $(20$ males and 40 females). Half received endotoxin $(500 \mu \mathrm{g} / \mathrm{kg})$ intraperitoneally at time 0 and $24 \mathrm{~h}$, and the controls received an equal volume of saline. At $48 \mathrm{~h}$ we killed the mice and removed their lungs. Treatment of mice with endotoxin increased glutathione reductase activity in the lung $55 \%(0.035 \pm 0.005$ to $0.054 \pm 0.010 \mu \mathrm{mol} \mathrm{NADPH}$ reduced $/ \mathrm{min} / \mathrm{mg}$ protein; mean $\pm \mathrm{SD}$; endotoxin different from control, $p<0.001)$. The increase in activity was the same for male and female mice. We measured the specific protein for glutathione reductase by Western analysis and mRNA for glutathione reductase using a slot-blot analysis and found that both increased roughly 2 -fold with endotoxin treatment. This suggests that endotoxin treatment resulted in either increased rate of transcription of glutathione reductase mRNA or increased mRNA stability. We conclude that endotoxin treatment increases glutathione reductase activity in the lung and that this increase in activity may play a role in subsequent protection from hyperoxia. (Pediatr Res 35: 311-315, 1994)
\end{abstract}

\section{Abbreviations}

FAD, flavin adenine dinucleotide

GAPDH, glyceraldehyde-3-phosphate dehydrogenase

$G R$, glutathione reductase

GSH, glutathione

GSSG, glutathione disulfide

MnSOD, manganese superoxide dismutase

TNF, tumor necrosis factor

Although the administration of supplemental oxygen to preterm infants if often necessary to sustain life, increased concentrations of oxygen can injure the lung, and oxygen toxicity may play a role in the genesis of chronic lung disease. Currently, much research on oxygen toxicity is directed at understanding the role of intracellular antioxidants in preventing tissue injury by reactive oxygen. One of the primary intracellular antioxidants

Received May 19, 1993; accepted October 7, 1993

Correspondence and reprint requests: Thomas N. Hansen, M.D., Department of Pediatrics, Baylor College of Medicine, Houston, TX 77030. is GSH. In a reaction catalyzed by the selenium-dependent and selenium-independent glutathione peroxidases, hydrogen peroxide and lipid hydroperoxides are reduced to water or their respective alcohols, whereas GSH is oxidized to GSSG. GSSG is subsequently reduced to GSH at the expense of NADPH oxidation in a reaction catalyzed by GR. The importance of GSH in protecting cells from reactive oxygen has been underscored by experiments showing that depletion of intracellular GSH $(1,2)$ or inhibition of glutathione peroxidase (3) or GR (4) significantly augments the toxic effects of oxygen on the lung.

Previously, we found that GR activity decreased more than $50 \%$ in the lungs of lambs dying of oxygen toxicity and that this decrease was associated with a near doubling of GSSG in their lung tissue (5). More recently, we showed that plasma concentrations of GSSG are increased in premature infants compared with adults, suggesting that this population may be deficient in GR (6). If reduced GR activity is playing a role in oxygen-induced lung injury, then increasing intracellular GR activity might help protect the lung from oxygen toxicity. The purpose of our experiments was to attempt to increase GR activity in the lungs of mice by treating the mice with endotoxin and to determine whether this increase in activity was associated with increased steady state concentrations of mRNA for GR. We chose endotoxin for these experiments for several reasons: 1 ) endotoxin is known to alter gene transcription through interactions with the lipopolysaccharide receptor and various transcription factors (7); 2) other investigators have shown that endotoxin alone $(8,9)$ or in combination with hyperoxia $(8,10-12)$ induces activities of a variety of antioxidants in whole lungs and lung cells in culture; and 3) endotoxin treatment of cultured pulmonary artery epithelial cells exposed to hyperoxia increases GR activity (12).

\section{MATERIALS AND METHODS}

Experimental design. We studied 60 6-wk old FVB mice $(20$ males and 40 females) weighing between 20 and $25 \mathrm{~g}$ (Taconic Farms, Germantown, NY). The mice resided in the animal care facility at Baylor College of Medicine and had free access to food and water throughout the experiment. At the start of the experiment, we randomly assigned half of the mice of each sex to receive two doses of lyophilized endotoxin resuspended in filtered normal saline (Salmonella abortus equi, Sigma Chemical Company, St. Louis, MO), $500 \mu \mathrm{g} / \mathrm{kg}$ intraperitoneally, $24 \mathrm{~h}$ apart, or two doses of an equal volume of saline (11). Twenty-four hours after the second injection, we anesthetized the mice with sodium pentobarbital ( $200 \mathrm{mg} / \mathrm{kg}$ intraperitoneally), opened their chests, removed both lungs, rinsed them in ice-cold saline, and blotted off the excess water. Then, we froze the right lung by clamping it between two metal plates that had been cooled in liquid nitrogen and stored it at $-80^{\circ} \mathrm{C}$ for subsequent isolation of RNA. Finally, we weighed the left lung and placed it into phosphate buffer $\left(0.01 \mathrm{M} \mathrm{NaPO}_{4}, \mathrm{pH} \mathrm{7.4)}\right.$ for immediate homogenization and measurement of GR activity. 
Measurement of GR activity: We measured GR activity with a modification of the method described by Bergemeyer (13). First, we added additional phosphate buffer to the tissues to adjust the final concentration to $50 \mathrm{mg}$ tissue $/ \mathrm{mL}$ of buffer and then homogenized the specimen with six 10-s cycles on a PT-10 Polytron (Brinkman Instruments, Westbury, NY) and centrifuged the homogenate at $10000 \mathrm{rpm}$ for $1 \mathrm{~h}$. Then, we mixed $57 \mu \mathrm{L}$ of supernate with $193 \mu \mathrm{L}$ of assay mixture $(0.1 \mathrm{M}$ Tris buffer (pH 8.0), $1 \mathrm{mM}$ NaEDTA, $7 \mathrm{mM}$ GSSG, and $0.255 \mathrm{mM}$ NADPH) in one well of a 96-well microtiter plate and measured the rate of consumption of NADPH as the change in OD per minute at wavelength $340 \mathrm{~nm}$ using a microtiter plate reader (Dynatech Laboratories, Chantilly, VA). In this reaction $1 \mathrm{U}$ of GR consumes $1 \mu \mathrm{mol}$ of NADPH per minute.

Measurement of $G R$ activity with added FAD. To assess the effects of riboflavin status on the increase in GR activity with endotoxin, we measured GR activity on lung supernates with and without added FAD (14). To paired samples we added FAD sufficient to raise the total concentration of FAD to $1 \mu \mathrm{M}$ or an equal volume of saline. Then we allowed the sample to incubate for $10 \mathrm{~min}$ at $37^{\circ} \mathrm{C}$ and measured GR activity as described above.

Measurement of protein concentration. We measured the protein concentration of the supernate with a modification of the method of Bradford (15). Briefly, we diluted each sample 1:40, added $25 \mu \mathrm{L}$ of the dilution to $200 \mu \mathrm{L}$ of dye (BioRad reagent diluted 1:5 and filtered; Bio-Rad Laboratories, Richmond, CA), loaded each specimen into a well of a 96 -well plate, and measured the absorbance at $600 \mathrm{~nm}$ wavelength with a microtiter plate reader. We calculated the protein concentration from a standard curve constructed with BSA.

Measurement of lung blood content. To measure lung blood content, we modified the method described by Cross et al. (16) for use on the microtiter plate reader. First, we incubated $25 \mu \mathrm{L}$ of sample with $175 \mu \mathrm{L}$ of a solution of $1 \%$ Triton in $0.1 \mathrm{M}$ Tris maleate $(\mathrm{pH} \mathrm{7.0)}$ for $5 \mathrm{~min}$ and measured the OD at $410 \mathrm{~nm}$. Then, we added $50 \mu \mathrm{L}$ of diothionite solution (equal volumes of $0.1 \mathrm{M} \mathrm{NaSO}_{4}$ and $0.1 \mathrm{M} \mathrm{NaOH}$ ) and repeated the measurements of $O D$ at $410 \mathrm{~nm}$. The amount of oxyhemoglobin reduced by the addition of diothionite provided an estimate of the amount of $\mathrm{Hb}$ in the sample. We constructed standard curves with whole mouse blood and from these curves calculated the blood content of the lung homogenate.

Isolation of total RNA and transfer to nitrocellulose. We isolated total RNA with the RNAzol technique (17) and then further purified the RNA by resuspending it in $250 \mu \mathrm{L}$ of resuspension buffer [ $10 \mathrm{mM}$ Tris (pH 7.6), $1 \mathrm{mM}$ EDTA, and 0.1\% SDS] and extracting it with $125 \mu \mathrm{L}$ of chloroform/isoamyl alcohol/butanol $(96: 4: 25, \mathrm{vol} / \mathrm{vol} / \mathrm{vol})$. To precipitate total RNA from this solution we adjusted the salt concentration to $100 \mathrm{mM}$ by adding 5 $\mathrm{M} \mathrm{NaCl}$ and $2 \frac{1}{2}$ vol of $100 \%$ ethanol and then froze the solution on dry ice. Next, we centrifuged the sample in a microfuge for 5 min to obtain an RNA pellet, washed the pellet in $70 \%$ ethanol, and then evaporated the ethanol and water by centrifugation under a vacuum (Speed Vac, Savant Instruments Inc., Farmingdale, NY). To separate the total RNA according to size, we resuspended the RNA pellet in $10 \mathrm{mM}$ Tris (pH 7.6), I $\mathrm{mM}$ EDTA, measured its concentration by measuring the absorption at $260 \mathrm{~nm}$, and loaded $20 \mu \mathrm{g}$ of denatured RNA into each lane of a $1.0 \%$ formaldehyde-agarose gel. We ran the gel overnight, transferred the RNA to a nitrocellulose filter, photographed it to ensure even transfer of ethidium bromide-stained RNA, and then baked the filter at $68^{\circ} \mathrm{C}$ for $3 \mathrm{~h}$.

RNA hybridization. We previously cloned a 720-bp fragment of the CDNA for mouse GR corresponding to the region between bp 231 and 951 of the human cDNA $(18,19)$ into the EcoRI site pGEM $-7 \mathrm{zf}(+)$ (Promega Corp., Madison, WI). Using this construct, we generated radioactive antisense transcripts to GR mRNA with the SP6 promoter and ${ }^{32}$ P-labeled uridine triphosphate (Amersham Life Sciences, Arlington Heights, IL). To prehybridize the membranes we soaked them for approximately
$3 \mathrm{~h}$ at $55^{\circ} \mathrm{C}$ in a solution of $50 \%$ formamide, $50 \mathrm{mM} \mathrm{Na}_{2} \mathrm{HPO}_{4}$, $0.8 \mathrm{M} \mathrm{NaCl}, 1.0 \mathrm{mM}$ EDTA, $0.5 \times$ Denhardt's solution, and $250 \mu \mathrm{g} / \mathrm{mL}$ of heat-denatured herring sperm DNA. Then we hybridized the membranes overnight at $55^{\circ} \mathrm{C}$ in $10 \mathrm{~mL}$ of the prehybridization solution plus $2 \times 10^{7} \mathrm{cpm}$ of the radioactive antisense transcripts. After hybridization, we washed the membranes three times for $20 \mathrm{~min}$ with $0.1 \times \operatorname{SSC}(0.015 \mathrm{M} \mathrm{NaCl}$ and $0.0015 \mathrm{M}$ trisodium citrate) and $0.1 \% \mathrm{SDS}$ at $68^{\circ} \mathrm{C}$ and then exposed $\mathrm{x}$-ray film to the hybridized filter at $-80^{\circ} \mathrm{C}$ to generate an autoradiogram. If the background radioactivity on the autoradiogram was too intense, we washed the nitrocellulose filter three times for $5 \mathrm{~min}$ with $2 \times \mathrm{SSC}$ at room temperature and then one time for $10 \mathrm{~min}$ in $2 \times$ SSC with $10 \mu \mathrm{g} / \mathrm{mL}$ of RNAse (Worthington Biochemicals, Freehold, NJ) at room temperature followed by a wash with $0.1 \%$ SDS and $0.1 \times$ SSC for $10 \mathrm{~min}$ at $55^{\circ} \mathrm{C}$. We then reexposed the filter to $x$-ray film to produce an autoradiogram.

Slot-blot analysis. To quantitate the increase in mRNA for GR with endotoxin treatment, we transferred $0.5,1.0$, and 2.0 $\mu \mathrm{g}$ of total RNA to a nitrocellulose filter with a slot-blot apparatus (Schleicher and Schuell, Keene, NH) and baked the filter at $68^{\circ} \mathrm{C}$. We prehybridized and then hybridized the filter with the same ${ }^{32} \mathrm{P}$-labeled antisense transcript that we used in the Northern-blot analysis, using the conditions described above. After washing the hybridized filter we used it to produce an autoradiogram. Then, with the autoradiogram as a template we excised each hybridized slot individually and counted it using standard scintillation techniques (20). We fit each row of the slot to a straight line and used the calculated $y$ intercept as a measurement of background. Finally, we then calculated the mean fold increase from control for each quantity of RNA loaded.

For controls we hybridized similarly loaded slot blots with an RNA probe made from the cDNA to mouse gene GADPH using a cDNA provided by Michael B. Prystowsky, M.D., Ph.D. (University of Pennsylvania). For use in these experiments we subcloned the 1.3-kb fragment into the plasmid Bluescript SK+ (Stratagene, La Jolla, CA). Prehybridization and hybridization conditions were identical to those described above.

Protein preparation and SDS-PAGE. To prepare the samples for gel electrophoresis we added 1 vol of $2 \times$ loading buffer [125 $\mathrm{mM}$ Tris ( $\mathrm{pH} \mathrm{6.8),6 \%} \mathrm{SDS,} 10 \%$ mercaptoethanol, $20 \%$ glycerol] to $1 \mathrm{vol}$ of homogenate ( $100 \mu \mathrm{g}$ of protein) with $1 \mu \mathrm{L}$ of $1 \%$ bromphenol blue. After heating the samples at $95^{\circ} \mathrm{C}$ for $5 \mathrm{~min}$, we loaded them on a polyacrylamide gel $[8 \%$ acrylamide $/ 0.1 \%$ SDS, $375 \mathrm{mM}$ Tris (pH 8.8) separating gel with a $4 \%$ acrylamide/ $0.1 \%$ SDS, $143 \mathrm{mM}$ Tris (pH 6.8) stacking gel] immersed in running buffer $(25 \mathrm{mM}$ Tris, $250 \mathrm{mM}$ glycine, $0.1 \% \mathrm{SDS})$ and separated the proteins by electrophoresis at a constant current.

Western blotting. After separating the lung tissue protein samples by electrophoresis, we transferred the separated proteins electrophoretically to an Immobilon-P filter (Millipore Corporation, Bedford, MA) in transfer buffer (192 mM glycine, $25 \mathrm{mM}$ Tris, $20 \%$ methanol). We then incubated the filter in $20 \mathrm{~mL}$ of blocking solution $[2 \%(\mathrm{wt} / \mathrm{vol})$ nonfat dried milk in Western buffer $(20 \mathrm{mM}$ Tris, $\mathrm{pH} 7.5$, and $150 \mathrm{mM} \mathrm{NaCl})]$ for $16 \mathrm{~h}$. We discarded the blocking solution and incubated the membrane in $10 \mu \mathrm{L}$ of primary antibody (antisera raised in rabbits against rat GR; provided by Joseph B. Warshaw, M.D., Yale University, New Haven, CT) (21) added to another aliquot of blocking solution for 1-3 h. After this incubation, we washed the filter three times in Western buffer, incubated it with $10 \mu \mathrm{L}$ of $1 \mu \mathrm{Ci}$ / $\mu \mathrm{L}{ }^{125}$ I protein A (ICN Radiochemicals, Irvine, CA), washed it three times in Western buffer, and dried it at $68^{\circ} \mathrm{C}$. After the filter was dry, we exposed it to $x$-ray film to obtain an autoradiogram and used the autoradiogram to estimate the fold increase in GR protein using laser densitometry.

Histologic analysis. To determine whether endotoxin treatment resulted in accumulation of leukocytes in the lung, we fixed samples of lungs from six mice (three controls and three endotoxin treated) by intratracheal instillation of a zinc formalin 
solution. We then examined hematoxylin and eosin-stained sections (one random section from each mouse) with light microscopy. We counted the number of neutrophils per 1000 total nuclei present in the section exclusive of cells in the lumen of capillaries (22). This determination required that we examine between 11 and 14 high-power fields per section.

Statistical analysis. We expressed all results as the means \pm 1 $\mathrm{SD}$ and used an unpaired $t$ test to compare endotoxin-treated animals with controls. To assess the effects of FAD on GR activity we compared treated samples with nontreated samples using a paired $t$ test. We considered a difference to be statistically significant if $p$ was $<0.05(23)$.

\section{RESULTS}

General. Mice treated with endotoxin were noted to have some ruffling of their fur and an increase in activity but no apparent change in appetite.

$G R$ activity. Pretreatment of mice with endotoxin increased GR activity in their lungs an average of $55 \%$ (Fig. 1). This increase was the same in both male and female mice. Supernatant protein concentrations were the same in treated and untreated mice $(2.27 \pm 0.32$ and $2.14 \pm 0.33 \mathrm{mg} / \mathrm{mL}$, respectively) as were lung blood contents $(2.94 \pm 0.46$ and $2.33 \pm 0.39 \mu \mathrm{L} / \mathrm{mL}$ of homogenate, respectively).

To determine whether riboflavin stores limited the increase in activity in endotoxin-treated mice, we measured GR activity on frozen lung samples with and without the addition of FAD. Although baseline GR activity was lower in the frozen than in the fresh samples, the addition of FAD increased baseline activity only $10 \%(0.019 \pm 0.002 \mathrm{U} / \mathrm{mg}$ protein without added FAD to $0.021 \pm 0.003 \mathrm{U} / \mathrm{mg}$ protein with FAD). Furthermore, endotoxin treatment increased GR activity roughly $50 \%$ with or without added FAD $(0.030 \pm 0.004 \mathrm{U} / \mathrm{mg}$ protein without added FAD and $0.033 \pm 0.004 \mathrm{U} / \mathrm{mg}$ protein with FAD).

Measurements of $G R m R N A$. Photographs of ethidium bromide-stained nitrocellulose membranes revealed that the gels were evenly loaded and that the transfer of RNA was uniform. Autoradiograms of the hybridized nitrocellulose membranes from the Northern analysis (Fig. 2) and from the slot blot (Fig. 3 ) revealed that the steady state concentrations of GR mRNA increased with endotoxin pretreatment, whereas the concentrations of GAPDH mRNA were not affected (Fig. 4). Analysis of the results obtained by counting the individual bands cut from the slot-blot membrane revealed that the steady state message

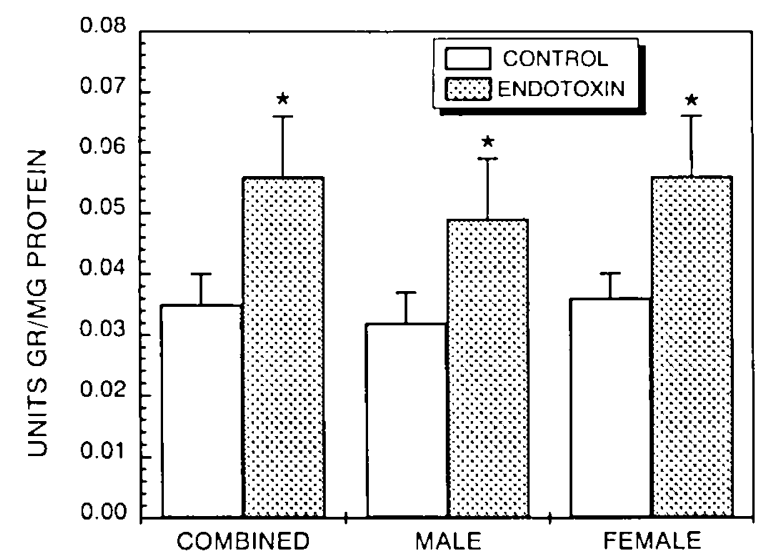

Fig. 1. Effects of endotoxin treatment on GR activity in male and female FVB mice. Sixty FVB mice ( 20 males and 40 females) were treated with either saline or two doses of $500 \mu \mathrm{g} / \mathrm{kg}$ endotoxin intraperitoneally $24 \mathrm{~h}$ apart. Lungs were removed $48 \mathrm{~h}$ after the first endotoxin dose. Baseline GR activity ( 1 U GR activity $=1 \mu \mathrm{mol} \mathrm{NADPH}$ reduced/ $\min )$ were similar in male and female mice. Endotoxin treatment increased GR activity $(*, p<0.05)$ a similar amount in both sexes of mice.

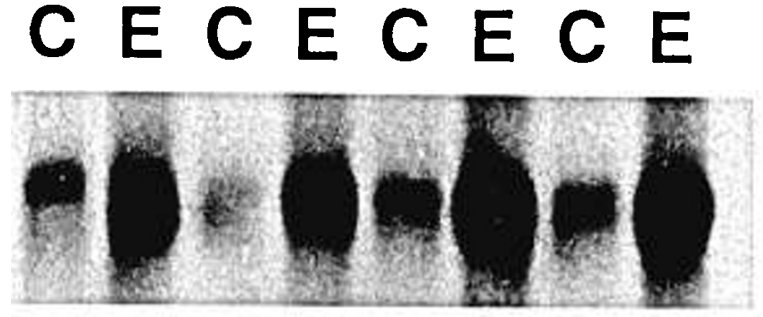

Fig. 2. Northern analysis of RNA obtained from saline-treated $(C)$ and endotoxin-treated $(E)$ mice. Twenty micrograms of total RNA were obtained from the lungs and separated on a $1.0 \%$ agarose formaldehyde gel, blotted onto nitrocellulose and hybridized with a 720-bp "2-P-labeled antisense transcript to mouse GR. The degree of hybridization is obviously stronger in the endotoxin lanes than in the control lanes.

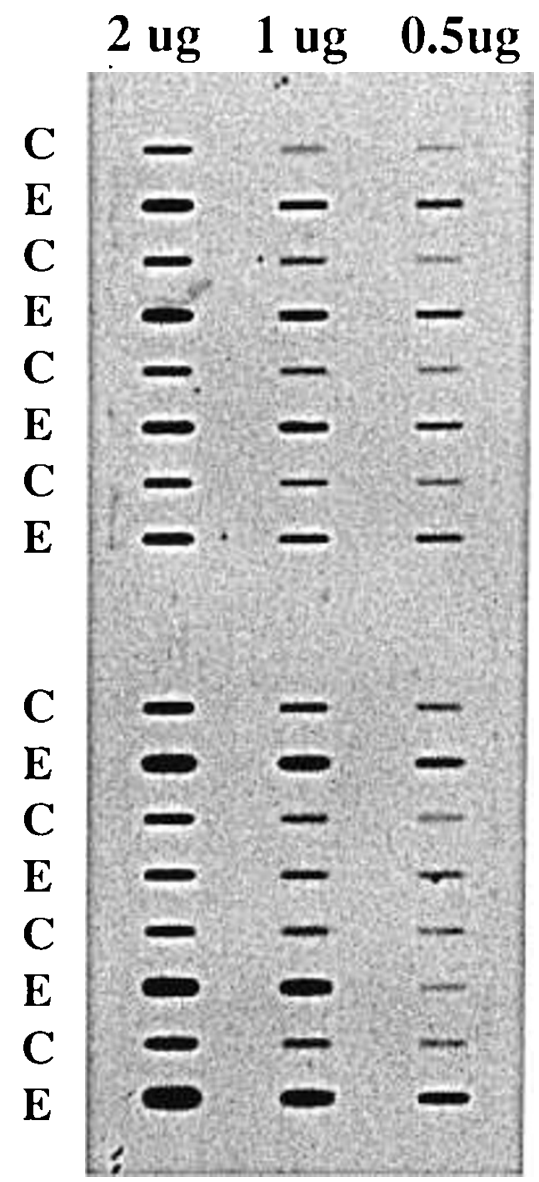

Fig. 3. Slot-blot analysis of RNA obtained from saline-treated $(C)$ and endotoxin-treated $(E)$ mice. The $0.5,1.0$, and $2.0 \mu \mathrm{g}$ of total RNA obtained from the lungs were transferred to a nitrocellulose filter with a slot-blot apparatus and then hybridized with a "P-labeled antisense transcript to mouse GR. Again, hybridization is stronger in the slots containing RNA from endotoxin-treated mice.

for GR more than doubled (Fig. 5), whereas that for GAPDH remained unchanged.

Measurements of $G R$ protein concentration. Laser densitometry of autoradiograms of the hybridized membranes from the Western analysis (Fig. 6) revealed that the steady state concentrations of GR protein increased roughly 2 -fold with endotoxin pretreatment.

IIistologic analysis. Examination of histologic sections revealed no evidence of lung injury. Counts of neutrophils per 1000 nuclei revealed that neutrophils increased from $1.7 \pm 0.3 \%$ of the total nuclei in the lungs of control mice to $3.5 \pm 0.8 \%$ in the lungs of endotoxin-treated mice $(p=0.02)$. 


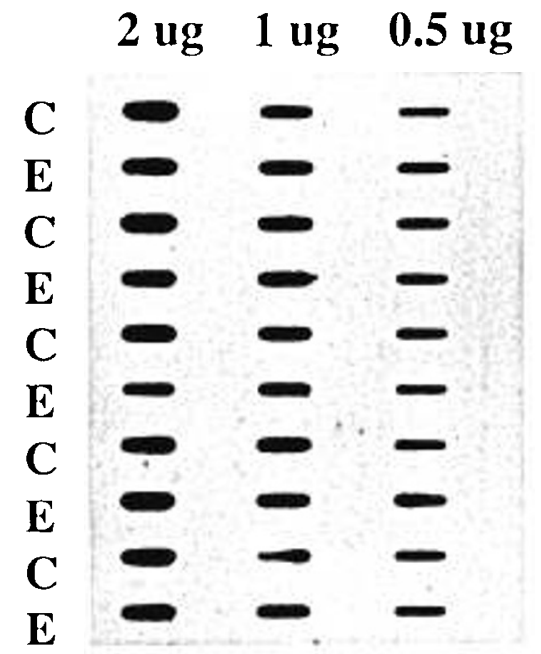

Fig. 4. Slot-blot analysis of RNA obtained from saline-treated $(C)$ and endotoxin-treated $(E)$ mice. The $0.5,1.0$, and $2.0 \mu \mathrm{g}$ of total RNA obtained from the lungs were transferred to a nitrocellulose filter with a slot-blot apparatus and then hybridized with a ${ }^{32} \mathrm{P}$-labeled antisense transcript to mouse GAPDH. In this case, slots in each column appear to be equally hybridized.

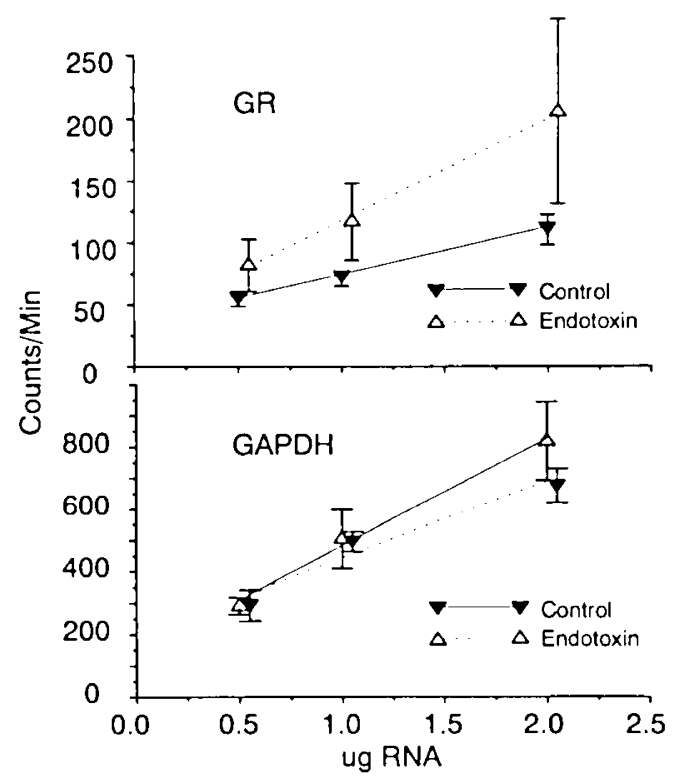

Fig. 5. Each slot from the slot blot was excised individually and counted with standard scintillation techniques. Endotoxin treatment clearly increases GR mRNA but does not affect GAPDH mRNA. If each row of the slot is fit to a straight line, the calculated $y$ intercept is a measurement of background. By subtracting this background, we can calculate the mean fold increase from control for each quantity of RNA loaded. For GR, this increase was roughly 2 -fold.

\section{DISCUSSION}

We were concerned that at least some of the increased GR activity after treatment with endotoxin might be caused by trapping in lung tissue of formed elements of blood that have high GR activity. Trapping of red cells could contribute to the observed increase in GR activity and the increase in specific protein concentration after treatment with endotoxin but would not explain the increase in GR mRNA. Furthermore, measurements of hemoglobin concentration in lung homogenates were the same in treated and untreated mice, indicating that trapping of red blood cells in the lung was not affected measurably by treatment of the mice with endotoxin. On the other hand, if white blood cells were recruited to the lung by endotoxin treat-

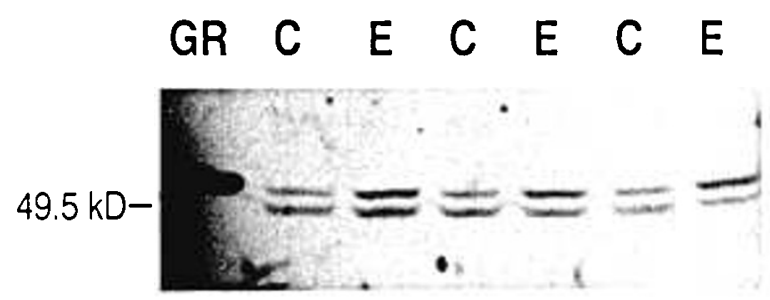

Fig. 6. Western analysis of protein obtained from saline-treated $(C)$ and endotoxin-treated $(E)$ mice. A total of $100 \mu \mathrm{g}$ of protein from the lungs were separated on a denaturing polyacrylamide gel, transferred to an Immobilon-P filter, and incubated with a primary antibody (anti-GR) and then with ${ }^{125}$ I protein A. Lane $l$ is a purified GR standard. The lanes containing lung protein demonstrate two bands. The top band migrates with purified standard and obviously increases with endotoxin treatment. The bottom band migrates faster than the GR standard, and its identity is not known. It could represent a proteolytic fragment of native GR or another member of the flavin protein family that copurified with the protein used to generate the polyclonal antibody. Laser densitometry of the top hand autoradiogram revealed that the specific GR protein increased 2-fold with endotoxin treatment.

ment, they might contribute to the increase in GR activity and specific protein concentration, as well as increased levels of GR mRNA. Previously, Koizumi et al. (22) showed that the number of neutrophils in the lungs of rats exposed to endotoxin increased from 2.5 to $5.4 \%$ of total lung nuclei. Interestingly, our results showing a doubling of neutrophils in the lung with endotoxin are almost identical to theirs. From these data, we calculated that for the influx of neutrophils to have accounted for the measured increase in lung GR activity, GR activity in the neutrophils would have to be 50 times greater than that of the other cells in the lung. This difference in activity would be greater by a factor of 10 than any lung tissue to other tissue difference in GR activity that we have measured to date (24). Furthermore, to account for the doubling of immunoreactive GR protein in the lung, the neutrophil would have to contain nearly 1000 times more GR protein than the other cells in the lung. In preliminary experiments, we have assessed the distribution of GR immunoreactive protein in the lung with a polyclonal rabbit antirat GR antibody (provided by Joseph B. Warshaw, M.D., Yale University, New Haven, CT). By light microscopy, the neutrophils do not stain more intensely than the surrounding alveolar epithelial cells. We conclude therefore that the increase in GR activity and specific protein concentration observed with endotoxin treatment could not be accounted for solely by trapping of formed elements of the blood with high GR activity. Of course, if endotoxin treatment increased the GR activity of formed elements of the blood already contained in the lung, this increase would contribute, at least in part, to the overall measured increase in GR activity.

Interestingly, the increase in GR activity was associated with a disproportionate increase in concentrations of GR protein and its mRNA. Other investigators have noted that endotoxin or cytokine-induced increases in mRNA may not result in proportional increases in enzyme activity $(25,26)$. In the experiments where specific protein concentrations were also measured (25). however, the results suggested that the "block" was at the level of protein translation. In our experiments, both GR mRNA and specific protein concentration increased out of proportion to measured activity, suggesting that the "block" was posttranslational. Our results are similar to those of Crouch et al. (21), who found that when newborn rabbits were exposed to hyperoxia, GR protein concentration in their lungs increased out of proportion to GR activity. All these results suggest that some process may be occurring in the cell that prevents the immunoreactive protein from being packaged into the fully functional enzyme. The specific GR translational product is an apoenzyme that must be associated with FAD for activity. Therefore, we were concerned that available riboflavin stores might have limited the 
magnitude of the increase in activity noted with endotoxin treatment. However, addition of FAD to the reactions did not substantially change baseline or induced GR activity, suggesting that riboflavin concentrations were not limiting. What other steps in the process of intracellular packaging of the functional GR enzyme might be rate limiting in these experiments are not clear. Recently, Clerch and Massaro (8) presented data suggesting that changes in the redox status of lung tissue may affect the activity of MnSOD. Specifically, they found that exposure of rats to hyperoxia decreased MnSOD activity in their lungs and that much of this decrease could be reversed by incubating lung extracts with the reducing agent DTT. Whether a similar phenomenon is responsible for the posttranslational block found in our experiments remains to be determined.

It is clear from our experiments that the increased GR activity and increased concentrations of specific GR protein are associated with increased steady state concentrations of mRNA for GR. Therefore, these data suggest that endotoxin must either increase the rate of transcription of GR mRNA or increase GR mRNA stability. In fact, recent data have shown that endotoxin treatment increases the rate of transcription of mRNA for MnSOD and glutathione peroxidase in the lungs of rats (8). Several mechanisms exist by which endotoxin treatment might increase the rate of transcription of GR mRNA. Endotoxin can increase transcription directly by binding to the lipopolysaccharide receptor and activating the transcription factors $N F-\kappa B$ and OTF-2 (7). On the other hand, endotoxin may cause release of cytokines in the lung such as TNF- $\alpha(7,27)$. Other investigators have shown that treatment of human alveolar carcinoma cells with TNF- $\alpha$ increases MnSOD activity by increasing the rate of transcription of its specific mRNA perhaps by activating $N F-\kappa B$. Interestingly, recent information has shown that TNF- $\alpha$ generates reactive oxygen in the cell, so it is also possible that TNF- $\alpha$ increases gene transcription through interactions with DNA elements and proteins that are sensitive to changes in redox status in the cell $(28,29)$.

On the other hand, endotoxin could increase steady state concentrations of mRNA for GR by increasing mRNA stability. Clerch et al. (30) and Clerch and Massaro (31) have shown that exposure of neonatal rats to hyperoxia increases catalase activity in their lungs by increasing the mRNA stability. Because endotoxin, through TNF- $\alpha$, may stimulate generation of intracellular reactive oxygen species, it is possible that a similar mechanism is involved in the increase in mRNA for GR that we observed with our experiments. Against this argument are the recent data showing that in endotoxin-treated rats, message stability for catalase and glutathione peroxidase increases only in the presence of hyperoxia (8).

In summary, endotoxin treatment increases GR activity and specific protein concentration in the lungs of mice, apparently by increasing steady state concentrations of mRNA for GR. Whether this increase in mRNA is the result of an increased rate of transcription or increased message stability is not clear. In either case, the results are interesting because they imply that control regions in the GR gene exist that can be manipulated to increase the rate of GR synthesis and perhaps allow us to more directly control intracellular GR activity and cellular response to injury by reactive oxygen.

\section{REFERENCES}

1. Deneke SM, Gershoff SN, Fanburg BL 1983 Potentiation of oxygen toxicity in rats by dietary protein or amino acid deficiency. $J$ Appl Physiol 54:147151

2. Smith LJ, Horcher P, Anderson J, Shamsuddin M 1990 Effect of fasting on the lung glutathione redox cycle in air- and oxygen-exposed mice: beneficial effects of sugar. J Lab Clin Med 116:717-723

3. Cross CE. Hasegawa G. Reddy KA, Omaye ST 1977 Enhanced lung toxicity of $\mathrm{O}_{2}$ in selenium-deficient rats. Res Commun Chem Pathol Pharmacol 16:685-706

4. Kehrer JP. Paraidathathu T 1984 Enhanced oxygen toxicity following treatment with 1,3-bis(2-chlorethy!)-1-nitrosourea. Fundam Appl Toxicol 4:760767

5. Hansen TN, Smith CV, Gest AL, Smith HW, Giesler M 1990 Biochemical manifestations of oxygen toxicity in the newborn lamb. Pediatr Res 28:613617

6. Smith CV, Hansen TN, Martin NE, McMicken IW. Elliott SJ 1993 Oxidan stress responses in premature infants during exposure to hyperoxia. Pediatr Res 34:360-365

7. Raetz CRH, Ulevitch RJ, Wright SD, Sibley CH. Ding A. Nathan CF 199 Gram-negative endotoxin: an extraordinary lipid with profound effects on eukaryotic signal transduction. FASEB J 5:2652-2660

8. Clerch LB, Massaro D 1993 Tolerance of rats to hyperoxia: lung antioxidant enzyme gene expression. J Clin Invest 91:499-508

9. Shiki Y, Meyrick BO, Brigham KL, Burr IM 1987 Endotoxin increases superoxide dismutase in cultured bovine pulmonary endothelial cells. Am J Physiol 252:C436-C440

10. Frank L, Yam J, Roberts RJ 1978 The role of endotoxin in protection of adult rats from oxygen-induced lung toxicity. J Clin Invest 61:269-275

11. Frank L, Summerville. J. Massaro D 1980 Protection from oxygen toxicity with endotoxin: role of the endogenous antioxidant enzymes of the lung. $j$ Clin Invest 65:1104-1110

12. Block ER, Patel JM, Sheridan NP 1985 Effect of oxygen and endotoxin on lactate dehydrogenase release, 5 -hydroxytryptamine untake, and antioxidan enzyme activities in endothelial cells. J Cell Physiol 122:240-248

13. Bergemeyer JU 1974 Methods of Enzymatic Analysis. Academic Press. New York, pp 465-466

14. Beutler E 1984 Red Cell Metabolism: A Manual of Biochemical Methods, 3rd Ed. Grune \& Stratton, New York, pp 72-73

15. Bradford M $1976 \mathrm{~A}$ rapid and sensitive method for the quantitation of microgram quantities of protein utilizing the principle of protein-dye binding. Anal Biochem 72:248-254

16. Cross CE. Watanabe TT, Hasegawa GK, Goralnik GN, Roertgen KE, Kaizu T, Reiser KM, Gorin AB, Last JA 1979 Biochemical assays in lung homogenates: artifacts caused by trapped blood after perfusion. Toxicol App Pharmacol 48:99-109

17. Chomczynski P, Sacchi N 1987 Single-step method of RNA isolation by acid guanidinium thiocyanate-phenol-chloroform extraction. Anal Biochem $162: 156-159$

18. Tutic M, Lu XA, Schirmer RH, Werner D 1990 Cloning and sequencing of mammalian glutathione reductase cDNA. Eur J Biochem 188.523-528

19. Cholin S, Tonoki H, Hansen TN. Ledley FD 1993 Expression of recombinant human glutathione reductase in eukaryotic cells after DNA-mediated gene transfer. Biochem Med Metab Biol 49:108-113

20. DeMayo FJ, Damak S, Hansen TN, Bullock DW 1991 Expression and regulation of the rabbit uteroglobin gene in transgenic mice. Mol Endocrinol 5:311-318

21. Crouch LS, Prough RA, Kennedy KA, Snyder JB, Warshaw JB 1988 Rat lung antioxidant enzyme activities and their specific proteins during hyperoxia. $J$ Appl Physiol 65:797-804

22. Koizumi M, Frank L, Massaro D 1985 Mitogenic effect of endotoxin on lung and tolerance of rats hyperoxia. J Appl Physiol 59:315-319

23. Zar JH Biostatistical Analysis, Prentice Hall, Englewood Cliffs, NJ, 1974

24. Hamburg DC, Tonoki H, Welty SE, Elliston JF. Montgomery CA. Geske R. Hansen TN 1993 Glutathione reductase activities vary between different tissues in mice. Pediatr Res 33:215A(abstr)

25. Iqbal J, Clerch LB, Hass MA. Frank L, Massaro D 1989 Endotoxin increases lung $\mathrm{Cu} . \mathrm{Zn}$ superoxide dismutase mRNA: $\mathrm{O}_{2}$ raises enzyme synthesis. Am J Physiol 257:L61-L64

26. Warner BB, Burhans MS, Clark JC, Wispe JR 1991 Tumor necrosis factor-c increases $\mathrm{Mn}$-SOD expression: protection against oxidant injury. Am J Physiol 260:L296-L301

27. Strieter RM, Remick DG, Lynch JP, Genord C Raiford C Spengler R, Kunkel SL 1989 Differential regulation of tumor necrosis factor- $\alpha$ in human alveolar macrophages and peripheral blood monocytes: a cellular and molecular analysis. Am J Respir Cell Mol Biol 1:57-63

28. Larrick JW, Wright SC 1990 Cytotoxic mechanism of tumor necrosis factor (x. FASEB J 4:3215-3223

29. Murphy HS, Shayman JA, Till GO, Mahroiugui M 1992 Superoxide responses of endothelial cells to C5a and TNF- $\alpha$ : divergent signal transduction pathways. Am J Physiol 263:L51-L59

30. Clerch LB, Iqbal J, Massaro D 1991 Perinatal rat lung catalase gene expression: influence of corticosteroid and hyperoxia. Am J Physiol 260:L428-L433

31. Clerch LB, Massaro D 1992 Oxidation-reduction-sensitive binding of lung protein to rat catalase mRNA. J Biol Chem 267:2853-2855 